\title{
Cheminformatics and Pharmacological Network Analysis for the Prediction of Molecular Mechanism of Herbal Drug Ligands
}

Lalit Raj Singh ( $\square$ lalitrajsingh@gmail.com )

Dev Sanskriti University

\section{Research Article}

Keywords: Drug-likeness, Clearance, Docking, Toxicity, Proteogenomic

Posted Date: October 11th, 2021

DOl: https://doi.org/10.21203/rs.3.rs-961457/v1

License: (1) (1) This work is licensed under a Creative Commons Attribution 4.0 International License.

Read Full License 


\section{Abstract}

The global demand for safer and more therapeutically effective medications is surging, providing medicinal plants a boost as suppliers of lead particles. The focus of current research is on an in silico comparison of one major bioactive principle and curatively designed new small drug-like molecule (scaffold analog). The recent study confirmed that the plant belongs to the Cyperaceae family and that it is Cyperus rotundus L. in taxonomy. The study's purpose was to uncover the mechanism of action of ligands/ scaffold analog by revealing genomic relationships, cellular signaling, and the top ten diseases/ illnesses that they were linked to. The scaffold analog showed promising drug-like potential as compared with cyperene. These investigations could broaden the reach of herbal medications, provide new formulations for current diseases or disorders, and pave the door for drug repurposing.

\section{Introduction}

The present work significantly emphasizes the curatively designed new small drug-like molecule (Scaffold analog) and in silico performance of comparative studies with a naturally found bioactive constituent (Cyperene) of the plant through ligand based approach (chemical similarity criteria) to unveil prospective target sites, genomic interactions, cellular signaling pathways, and their associated diseases/disorders through proteogenomic analysis to better understand their mode of action. Herbal medicine has been used by humans for healing purposes in many treatment systems (Ayurveda, Unani, Homeopathy, and Siddha) from ancient times, and has been described as an essential source of medicine even in the present period[1]. Obesity, remittent fever, monthly irregularities, bowel disorders, colitis, diarrhea, vomiting, uterine contraction, bad breath, and other neuromuscular-related issues are all treated by Nut Sedge (Cyperus rotundus L.)[2, 3]. The major therapeutic agents are found in rhizomes of the herb. The plethora of bioactive constituents is found in it including cyperene, $a$-cyperone, humulin, $\beta$ selinene, $\alpha$-selinene, cyperotundone, zierone, $\alpha$-calacorene, campholenic aldehyde, pinene, $\gamma$-muurolene, longiverbenone, $\beta$-caryophyllene oxide, and limonene [4]which represents different classes of secondary metabolites such as alkaloids, phenols, tannins, saponins, steroids, coumarins, flavonoids diterpenoids, and triterpenoids[5, 6]. Herbal-derived ligands and targeted therapeutic approaches may be successfully worked on using in silico approaches[7]. The ligands (bioactive component, scaffold analog) of Cyperus rotundus $\mathrm{L}$. were evaluated to find its molecular activities at different target sites by maintaining a curative space for drug discovery, drug reuse[8], development, advancement, and innovative results[9]. These efforts include an in silico approach to cheminformatics[10], and proteogenomic analysis[11] including physicochemical analysis, pharmacokinetics, pharmacodynamics, medicinal chemistry, drug similarities, designing of novel scaffolding analog, target predictions, molecular docking, identification of genes, genomic interactions, cellular signaling, and their biological insights (top ten diseases/ disorders regulated by these interactive genes via identifying the target sites of ligands) through representative overexpression analysis (ORA)[12], and Network Topology-based Analysis (NTA)[13]. The topological polar surface area (TPSA) of a molecule is defined as the surface sum of all polar atoms or molecules including oxygen, nitrogen, and their attached hydrogen atoms[5]. Log $\mathrm{P}$ is the logarithm of the partition 
coefficient $(P)$ when one of the solvents is water and the other is a non-polar solvent. For the optimal results, the $\log P$ value is $0<\log P<3, \log P<0$ : poor lipid bilayer permeability, and $\log P>3$ : poor aqueous solubility. It is a measure of the lipophilicity or hydrophobicity of the compound. XLogP3 predicts the octanol/water partition coefficient of an organic compound. It is based on the group contribution method with suitable corrections. Water solubility ( $\log S$ ) is represented from insoluble $<-10<$ poorly $<-6<$ moderately $<-4<$ soluble $<-2$ very $<0<$ highly soluble. The pharmacokinetics parameters include the absorption (gastrointestinal absorption, p-glycoprotein substrate), distribution (blood-brain barrier), metabolism (CYP1A2 inhibitor, CYP2C19 inhibitor, CYP2C9 inhibitor, CYP2D6 inhibitor, and CYP3A4 inhibitor), elimination (elimination half time $\left(\mathrm{T}^{1 / 2}\right): 3 \mathrm{~h}<\mathrm{T}^{1 / 2}<8 \mathrm{~h}$ and clearance $(\mathrm{cl})$ : $5 \mathrm{ml} / \mathrm{min} / \mathrm{kg}<\mathrm{cl}<15 \mathrm{ml} / \mathrm{min} / \mathrm{kg}$, and toxicity (human ether-a-go-go-related gene(hERG- category 0 : non blocker; category 1: blocker), human hepatotoxicity (H-HT- category 0 : negative; category 1: positive), Ames mutagenicity-category 0 : negative; category 1 : positive, skin sensitization-category 0 : non sensitizer; category 1: sensitizer, drug-induced liver injuries (DILI-category 0: negative; category 1: positive), and FDA maximum recommended daily dose-category 0 : FDAMDD negative; category 1 : FDAMDD positive). The bioactivity scores of the ligands on different target sites such as GPCR ligand, ion channel modulator, kinase inhibitor, nuclear receptor ligand, protease inhibitor, and enzyme inhibitor activities are covered under pharmacodynamics. The bioactivity of screened molecules may then be calculated as a sum of activity contributions of fragments in these molecules. This provides a molecule activity score (a number, typically between -3 and 3 ). Molecules with the highest activity score have the highest probability to be active. The drug-likeness properties were evaluated by the application of 'Lipinski Rule of Five', 'Ghose's Rule', 'Veber's Rule', 'Muegge's Rule', and 'Egan Rule'[14-16]. Pan-assay interference structure (PAINS) analysis is performed on compounds having desirable physicochemical properties to determine their toxicity. This assay is also called toxicophores because of the presence of some group elements that disrupt the biological processes through interference with DNA or protein which results in fatal conditions such as carcinogenicity and hepatotoxicity. Brenk analysis gives an idea about structural alert including chirality and steric hindrances. The lead-likeness comprises the ligands having $250 \leq M W \leq 350, X L o g P \leq 3.5$, and no. of rotatable bonds $\leq 7$. The synthetic accessibility score from 1 (very easy) to 10 (very difficult) to synthesize.

\section{Materials And Methods \\ 2.1 Details of the Plant}

Hindi Name: Motha

Common Name: Nut sedge

Latin Name: Cyperus rotundus Linn.

Family: Cyperaceae

\subsection{General procedure}


One major bioactive Phyto-constituents was selected from the experimental plant material based on their activities and a scaffold analog was drawn by ChemBioDraw[17], comparatively evaluated for their physicohemical, pharamacokinetics, pharmacodynamics, medicinal chemistry, and drug-likeness properties by the assistance of SwissADME[18], ADMET lab[19,20], and Molinspiration Cheminformatics Software[21]. The targets of the ligands were predicted based on probability by using Swiss Target Prediction[22]. The molecular docking was assisted by Swiss DOCKING an open-access web server[23] by feeding the PDB file of the target[24] and .mol2 file of ligand molecules. The .mol, .mol2, and PDB files were reviewed by PyMOL[25], and Jsmol[26] respectively. The docking results were obtained in the form of .chimerax format which was further observed by UCSF Chimera[27,28]. The bioactive properties, halflife (T1/2), clearance time, and toxicity profiles of all the four ligands were undertaken with the assistance of the ADMET lab[29]. The cellular signaling pathways and gene-gene interactions were also studied for a comprehensive view of the prospective mode of action of ligand molecules at the genomic level through the WebGestalt (WEB-based Gene Set Analysis Toolkit), 2019[30].

\section{Results And Discussion}

\subsection{Physicochemical, Pharmacokinetics, Pharmacodynamics, Drug-Likeness, and Medicinal chemistry attributes of the ligands}

The cheminformatics of the bioactive constituent (Cyperene) and a Scaffold analog are given in Table 1. The IUPAC nomenclatures were used for further generation of smile notations and .mol2 files[31] for further exploration. A scaffold analog (SA) was drawn by taking into consideration optimum cheminformatics parameters. Table 1 shows the ligands' IUPAC names, smile notation, and twodimensional structure. The molecular weight, hydrogen bond acceptor (HBA), hydrogen bond donors (HBD), lipophilicity (LogP, XLogP3), water solubility (Log S), and topological surface area are all shown in Table 2. The scaffold analog shows prominent and favourable properties as compared to cyperene.

Table 1 Showing ligand name, IUPAC name, and 2-D structure 


\begin{tabular}{|l|l|l|l|l|}
\hline S.N. & Ligand Name & IUPAC Name & Smile notation & Structure \\
\hline 1. & Cyperene & $\begin{array}{l}4,10,11,11-\text { tetramethyl } \\
\text { tricyclo[5.3.1.01,5]unde } \\
\text { c-4-ene }\end{array}$ & $\begin{array}{l}\mathrm{CC} 1 \mathrm{CCC} 2 \mathrm{CC} 3=\mathrm{C}(\mathrm{CC} \\
\mathrm{C} 13 \mathrm{C} 2(\mathrm{C}) \mathrm{C}) \mathrm{C}\end{array}$ \\
\hline 2. & $\begin{array}{l}\text { Scaffold analog } \\
\text { (SA) }\end{array}$ & $\begin{array}{l}\text { 1-(2,2- } \\
\text { dimethylpropyl)-3,5,7- } \\
\text { trihydroxy-2,7a- } \\
\text { dihydro-1H-indene-2- } \\
\text { carboxylic acid }\end{array}$ & $\begin{array}{l}\mathrm{CC}(\mathrm{C})(\mathrm{C}) \mathrm{CC} 2 \mathrm{C}(\mathrm{C}(=\mathrm{O} \\
\mathrm{O}) \mathrm{C}(\mathrm{O})=\mathrm{C} 1 \mathrm{C}=\mathrm{C}(\mathrm{O}) \mathrm{C} \\
\mathrm{C}(\mathrm{O}) \mathrm{C} 12\end{array}$ \\
\hline
\end{tabular}

Table 2

Showing comparative physicochemical properties of Cyperene and Scaffold analog (SA)

\begin{tabular}{|llllllll|}
\hline S.N. & Name & M.W. & HBA & HBD & $\begin{array}{l}\text { Lipophilicity } \\
\text { (LogP, } \\
\text { XLogP3) }\end{array}$ & $\begin{array}{l}\text { Water Solubility } \\
\text { (LogS) }\end{array}$ & TPSA \\
\hline $1 . \quad$ & Cyperene & $204.36 \mathrm{~g} / \mathrm{mol}$ & 0 & 0 & $3.17,4.32$ & -3.83 (soluble) & $\begin{array}{l}0.00 \\
\mathrm{~A}^{2}\end{array}$ \\
\hline 2. & $\begin{array}{l}\text { Scaffold } \\
\text { analog }\end{array}$ & $280.32 \mathrm{~g} / \mathrm{mol}$ & 5 & 4 & $1.32,2.44$ & -2.92 (soluble) & $\begin{array}{l}97.98 \\
\mathrm{~A}^{2}\end{array}$ \\
\hline
\end{tabular}

The cheminformatics data generates significant details about the ligands which have been widely used to screen out potential compounds with desirable properties. The characterization of ligands architecture for drug-like characteristics has further explored the pathways for curated drugs formulations and promising drug repurposing compounds. Table 3 shows the ligands' pharmacokinetics including absorption (Gl absorption, P-glycoprotein substrate), distribution (blood-brain barrier), metabolism, elimination ( $T^{1 / 2}$, clearance), and toxicity profiles. The scaffold analog shows good results within the acceptable range of all the stated parameters as compared with cyperene. 
Table 3

Showing the pharmacokinetic profile of the Cyperene and Scaffold analog (SA)

\begin{tabular}{|c|c|c|c|c|c|c|c|}
\hline \multirow[t]{2}{*}{ S.N. } & \multirow[t]{2}{*}{ Name } & \multirow[t]{2}{*}{ Absorption } & \multirow[t]{2}{*}{ Distribution } & \multirow[t]{2}{*}{ Metabolism } & \multicolumn{2}{|c|}{ Elimination } & \multirow{2}{*}{$\begin{array}{l}\text { Toxicity } \\
\text { (Probability, } \\
\text { Category) }\end{array}$} \\
\hline & & & & & $\mathrm{T}^{1 / 2}$ & Clearance & \\
\hline \multirow[t]{6}{*}{1.} & \multirow[t]{6}{*}{ Cyperene } & \multirow{6}{*}{$\begin{array}{l}\text { Gl } \\
\text { absorption } \\
\text { (Low) } \\
\text { P-gp } \\
\text { substrate } \\
\text { (No) }\end{array}$} & \multirow[t]{6}{*}{$\begin{array}{l}\text { BBB } \\
\text { permanent } \\
\text { (No) }\end{array}$} & $\begin{array}{l}\text { CYP1A2 } \\
\text { inhibitor } \\
\text { (No) }\end{array}$ & \multirow[t]{6}{*}{$0.045 \mathrm{~h}$} & \multirow[t]{6}{*}{$\begin{array}{l}16.041 \\
\mathrm{ml} / \mathrm{min} / \mathrm{kg}\end{array}$} & $\begin{array}{l}\text { hERG } \\
(0.014,0)\end{array}$ \\
\hline & & & & CYP2C19 & & & $\begin{array}{l}\mathrm{H}-\mathrm{HT} \\
(0.142,0)\end{array}$ \\
\hline & & & & (Yes) & & & $\begin{array}{l}\text { Ames } \\
(0.006,0)\end{array}$ \\
\hline & & & & $\begin{array}{l}\text { CYP2C9 } \\
\text { inhibitor } \\
\text { (Yes) }\end{array}$ & & & $\begin{array}{l}\text { Skin Sen } \\
(0.207,0)\end{array}$ \\
\hline & & & & $\begin{array}{l}\text { CYP2D6 } \\
\text { inhibitor } \\
\text { (No) }\end{array}$ & & & $\begin{array}{l}\text { DILI } \\
(0.052,0)\end{array}$ \\
\hline & & & & $\begin{array}{l}\text { CYP3A4 } \\
\text { inhibitor } \\
\text { (No) }\end{array}$ & & & $\begin{array}{l}\text { FDA MDD } \\
(0.229,0)\end{array}$ \\
\hline \multirow[t]{6}{*}{2.} & \multirow[t]{6}{*}{$\begin{array}{l}\text { Scaffold } \\
\text { analog }\end{array}$} & $\begin{array}{l}\text { GI } \\
\text { absorption } \\
\text { (High) }\end{array}$ & \multirow{6}{*}{$\begin{array}{l}\text { BBB } \\
\text { permanent } \\
\text { (No) }\end{array}$} & $\begin{array}{l}\text { CYP1A2 } \\
\text { inhibitor }\end{array}$ & \multirow[t]{6}{*}{$0.786 \mathrm{~h}$} & \multirow{6}{*}{$\begin{array}{l}10.186 \\
\mathrm{ml} / \mathrm{min} / \mathrm{kg}\end{array}$} & $\begin{array}{l}\text { hERG } \\
(0.023,0)\end{array}$ \\
\hline & & \multirow{5}{*}{$\begin{array}{l}\text { P-gp } \\
\text { substrate } \\
\text { (Yes) }\end{array}$} & & $\begin{array}{l}\text { CYP2C19 } \\
\text { inhibitor }\end{array}$ & & & $\begin{array}{l}\mathrm{H}-\mathrm{HT} \\
(0.2,0)\end{array}$ \\
\hline & & & & (No) & & & $\begin{array}{l}\text { Ames } \\
(0.12,0)\end{array}$ \\
\hline & & & & $\begin{array}{l}\text { CYP2C9 } \\
\text { inhibitor } \\
\text { (No) }\end{array}$ & & & $\begin{array}{l}\text { Skin Sen } \\
(0.486,0)\end{array}$ \\
\hline & & & & $\begin{array}{l}\text { CYP2D6 } \\
\text { inhibitor } \\
\text { (No) }\end{array}$ & & & $\begin{array}{l}\text { DILI } \\
(0.247,0)\end{array}$ \\
\hline & & & & $\begin{array}{l}\text { CYP3A4 } \\
\text { inhibitor } \\
\text { (No) }\end{array}$ & & & $\begin{array}{l}\text { FDA MDD } \\
(0.353,0)\end{array}$ \\
\hline
\end{tabular}

The pharmacodynamics (bioactivity score at different targets), drug-likeness, and medicinal chemistry attributes of the ligands are given in Table 4. The scaffold analog showed most promising attributes without any violations and alerts as compared to cyperene that indicates that there is fair possibility of developing new drug-likeness molecules from bioactive constituents of the other medicinal plants also in future. 
Table 4

Showing the pharmacodynamics, drug-Likeness, and medicinal chemistry profiles of the Cyperene and Scaffold analog (SA)

\begin{tabular}{|c|c|c|c|c|}
\hline S.N. & Name & $\begin{array}{l}\text { Pharmacodynamics } \\
\text { (Bioactivity Score) }\end{array}$ & Drug-Likeness & Medicinal Chemistry \\
\hline \multirow[t]{7}{*}{1.} & \multirow[t]{7}{*}{ Cyperene } & GPCR ligand $(-0.35)$ & Lipinski (Yes) & \multirow{7}{*}{$\begin{array}{l}\text { PAINS ( } 0 \text { alert) } \\
\text { Brenk ( } 1 \text { alert: isolated_alkene) } \\
\text { Lead-Likeness (No; } 2 \text { violations: } \\
\text { MW<250, XLOGP3>3.5) } \\
\text { Synthetic accessibility (5.34, } \\
\text { moderate) }\end{array}$} \\
\hline & & Ion channel & Ghose (Yes) & \\
\hline & & 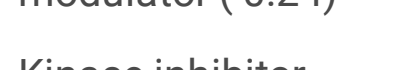 & Veber (Yes) & \\
\hline & & $(-1.06)$ & Egan (Yes) & \\
\hline & & $\begin{array}{l}\text { Nuclear receptor- } \\
\text { ligand }(-0.16)\end{array}$ & $\begin{array}{l}\text { Muegge (No; } 1 \\
\text { violation: } \\
\text { Heteroatoms }<2 \text { ) }\end{array}$ & \\
\hline & & $\begin{array}{l}\text { Protease inhibitor } \\
(-0.82)\end{array}$ & Bioavailability score & \\
\hline & & $\begin{array}{l}\text { Enzyme inhibitor } \\
(-0.17)\end{array}$ & & \\
\hline \multirow[t]{7}{*}{2.} & \multirow{7}{*}{$\begin{array}{l}\text { Scaffold } \\
\text { analog }\end{array}$} & GPCR ligand $(-0.10)$ & Lipinski (Yes) & PAINS (0 alerts) \\
\hline & & Ion channel & Ghose (Yes) & Brenk (0 alerts) \\
\hline & & & Veber (Yes) & Lead-Likeness (Yes) \\
\hline & & $(-0.45)$ & Egan (Yes) & \multirow{4}{*}{$\begin{array}{l}\text { Synthetic accessibility ( } 5.07 \text {, } \\
\text { moderate) }\end{array}$} \\
\hline & & Nuclear receptor & Muegge (Yes) & \\
\hline & & $\begin{array}{l}\text { Protease inhibitor } \\
(0.03)\end{array}$ & \multirow[t]{2}{*}{$\begin{array}{l}\text { Bioavailability score } \\
(0.56)\end{array}$} & \\
\hline & & $\begin{array}{l}\text { Enzyme inhibitor } \\
(0.27)\end{array}$ & & \\
\hline
\end{tabular}

The naturally found active constituent of the herbs i.e Cyperene showed Muegge (01 violation), Brenk (1alert), lead-likeness ( 02 violations), bioavailability score of 0.55 , and moderate synthetic accessibility(5.34), while promising novel scaffold analog(SA) showed no violations and alerts along with higher bioavailability and easier to synthetic accessibility. Cyperene showed the highest bioactivity on the nuclear receptor target site (-0.16) while scaffolding analog (SA) highest bioactivity on the enzyme inhibitor target site (0.27).

\subsection{Drug targets and molecular docking}


When compared to Cyperene, a key bioactive constituent of Cyperus rotundus L., the Scaffold analogue, a novel and innovative product, showed promising physicochemical, pharmacokinetics, pharmacodynamics, drug-likeness, and medicinal chemistry profiles. SWISS Target Prediction Software assessed both ligands (Cyperene and SA) and projected target sites based on probability as shown in the figure 1 and 2 respectively.

The .mol and .mol2 files of the SA were not available on any database because it was a newly drawn small molecule. The .mol2 file was created and then verified, viewed, and standardized by UCSF Chimera. The .mol files of Cyperene were available on Zinc 15 and PubChem databases, which were further converted to .mol2 files through Open Babel[35] or CORINA Software[36]. As indicated in Table 5, the decision to choose target sites, classes, and PDB ids was based on the outcomes of Swiss target prediction, bioactivity scores at specific target sites, and ligand compatibility with PDB. PDB files and ligands were standardized and selected for further analysis. In the PDB files, all the missing parameters such as atoms, missing loops, side chains, and residues were checked and inserted. The incorrect chirality, steric clashes, water molecules, and non-protein residues were removed via structure optimization and energy minimization using chimera, and Chiron energy minimization and refinement tool. The structure of the ligand was carefully inspected to make sure that the topology of the molecule is correct, as well as its protonation state and tautomeric form.

Table 5

Showing Promising targets of the ligands (Cyperene and SA) and their PDB Ids

\begin{tabular}{|llllll|}
\hline S.N. & Name & Target & Class & $\begin{array}{l}\text { Common } \\
\text { name }\end{array}$ & $\begin{array}{l}\text { PDB } \\
\text { Id }\end{array}$ \\
\hline 1. & Cyperene & $\begin{array}{l}\text { Peroxisome proliferator- } \\
\text { activated } \\
\text { Receptor alpha }\end{array}$ & $\begin{array}{l}\text { Nuclear } \\
\text { receptor }\end{array}$ & PPARA & 3et1 \\
\hline 2. & $\begin{array}{l}\text { Scaffold } \\
\text { analog }\end{array}$ & $\begin{array}{l}\text { Leukotriene A4 } \\
\text { Hydrolase }\end{array}$ & Protease & LTA4H & 4DPR \\
\hline
\end{tabular}

Molecular Docking: The molecular docking was executed to ascertain the binding conformations (Figures (3et1-Cyperene):3-6 and Figures (4DPR-SA): 7-10) of the protein-ligand complex using Swiss docking.

The binding conformation aids to reveal the binding energy of the ligands with target sites. The visualization of biomolecules illustrates the dynamic aspects of molecular simulation docking and its application in structural biology. The docking helped us to know the interaction of ligands and proteins at the atomic level to significantly characterize the behavior of the ligands while interacting with target proteins. 
The binding free energy $\left(\Delta \mathrm{G}_{\text {bind }}\right)$ comprises Vander Waals energy $\left(\Delta \mathrm{G}_{\mathrm{vdw}}\right)$, the sum of electrostatic energy $\left(\Delta G_{\text {elect }}\right)$, the sum of hydrogen bond and desolvation energy $\left(\Delta G_{H b o n d}\right)$, the sum of final total internal energy $\left(\Delta G_{\text {conform }}\right)$, the sum of torsional free energy $\left(\Delta G_{\text {tor }}\right)$, and the sum of unbound system energy $\left(\Delta \mathrm{G}_{\text {solv }}\right)$. The energies of cyperene and scaffold analog $(\mathrm{SA})$ are shown in Table 6.

Table 6

Showing energies of the Cyperene and Scaffold analog (SA)

\begin{tabular}{|llll|}
\hline S.N. & Energy & Cyperene $(\mathrm{Kcal} / \mathrm{mol})$ & Scaffold analog $(\mathrm{Kcal} / \mathrm{mol})$ \\
\hline 1. & Simple Fitness & 8.94543 & 6.24943 \\
\hline 2. & Full Fitness & -3195.7913 & -2348.1462 \\
\hline 3. & Inter Full & -22.9567 & -30.8849 \\
\hline 4. & Intra Full & 33.5883 & 20.1136 \\
\hline 5. & Solv Full & -3634.68 & -2732.95 \\
\hline 6. & Surf Full & 428.257 & 395.575 \\
\hline 7. & Extra Full & 0.0 & 0.0 \\
\hline 8. & deltaGcompsolvpol & -3634.68 & -2732.95 \\
\hline 9. & deltaGcompsolnonpol & 428.257 & 395.575 \\
\hline 10. & deltaGprotsolvpol & -3641.95 & -2735.36 \\
\hline 11. & deltaGprotsolvnonpol & 430.093 & 395.765 \\
\hline 12. & deltaGligsolvpol & -0.915856 & -15.211 \\
\hline 13. & deltaGligsolvnonpol & 10.6932 & 9.36669 \\
\hline 14. & deltaGvdw & -22.9567 & -30.8849 \\
\hline 15. & deltaGelec & 0.0 & 0.0 \\
\hline 16. & deltaG & -6.84599 & -6.7373595 \\
\hline & & & \\
\hline
\end{tabular}

The Swiss Docking is based on an algorithm that consists of several steps such as a large number of bonding modes (BMs) are generated, either in the user-defined box (local docking) or near to the target cavities of the whole protein surface (blind docking). Concurrently, their CHARMM energies are evaluated. Then BMs with the most favorable energies are ranked, taking into consideration the solvation model. The results of binding free energies (DIGibind) and compatibility of 3-D crystalline protein structures with ligands are quite important for better elucidating the biochemical pathways. However, the present 
research discerns the ligand based approach wherein the ligand/ scaffold analog showed activities on multiple targets. The purpose of molecular docking herein is just to establish the binding energy of scaffold analog irrespective of binding affinity. That generated the primitive idea about binding activity.

After swiss target prediction, Cyperene was docked to Peroxisome proliferator-activated receptor alpha (PPARA) a target site of nuclear receptor but it could not be materialized in the case of scaffold analog (SA) due to non-compatibility of enzyme inhibitor (0.27) and nuclear receptor (0.07) target sites. The molecular docking was done on Leukotriene A4 hydrolase, a target site of protease inhibitor which shows a bioactivity score of 0.03 . Hence, it became crucial to conduct proteogenomic analysis to have better insights into the genomic interactions and molecular mechanism of action of the ligand/ SA.

\subsection{Proteogenomic analysis}

Proteogenomic analysis: The analysis was performed through Over-representation analysis (ORA) and Network topology analysis (NTA) for better understanding and knowing the behavior of genomic interactions and their regulated pathways. It was quite difficult to perform the docking studies of ligands and their all predicted target sites due to the non-availability of 3D structures of most of the proteins in Protein databases (PDB) and their compatibility with the ligands for accurate results. Moreover, it was very difficult to get the crystalline 3D structures of all proteins for extensive studying of ligand-target interaction[37]. Hence, it became crucial to conduct Proteogenomic analysis through ORA and NTA. We selected 26, and 40 target genes to understand the genomic interactions of Cyperene, and Scaffold ligands respectively. Network topology analysis (NTA) was performed by following the sequential pathways:-

Homosapiens $>$ NTA $>$ Network>PPI biogrid $>$ Gene symbol>Gene feeding $>$ Submit $>$ Result.

Over-representation analysis is also a sequential pathway that is performed to find out the cellular signaling pathways and most promising (top ten) diseases/ disorders controlled by these interactive genes.

(i) The sequential pathways for analyzing the cellular signaling:-

ORA $>$ Pathway $>$ Reactome>Gene symbol>Genome $>$ Submit $>$ Result.

(ii) The sequential pathways for analyzing interactive genes and their associated diseases/disorders:-

ORA>Disease>Disgenet>genome>Submit>Result

\subsubsection{Cyperene Interaction grid and signaling pathways:}

The cyperene may prove as a potential remedy for enlarged polycystic ovaries, prostatic intraepithelial neoplasia, female infertility, marijuana abuse, insulin resistance, mental depression, obesity, mood disorders, depressive disorders, and schizophrenia. 


\subsubsection{Scaffold Analog interaction grid and signaling pathway:}

The novel scaffold analog may prove as a remedy for anuria, Allanson pantzar McLeod syndrome (a genetic disorder), endogenous depression (melancholia), coronary restenosis, widely patent fontanelles, and sutures, nephrosis, Behcet's syndrome (autoimmune disorder), atherosclerosis, cerebrovascular accident, and heart failure. The prominence of herbals is ostensibly observed among comestible practices as well as in holistic healthcare practices embraced by society[6]. The global demand for prospective lead molecules is growing, and active medication particles have been diverted through the use of in silico techniques to speedy health problem resolution[7]. There is always a demand for safer and more effective therapeutic compounds, which can be answered by doing Cheminformatics and Proteogenomic studies on indigenous herbal medicine connections. In the present study ligand-target approach of the investigation was performed to elucidate the pathways, interaction of genes involved in specific cellular pathways, and controlling the specific diseases, and disorders. The ligands and their generalized mode of action affect genes and are responsible for which diseases/ disorders. The conventional and CAM (complementary and alternative) is a promising strategy for fighting against cancer. There is a huge demand for newly discovered phytochemicals for performing preclinical and epidemiological studies to identify their molecular signatures[8]. There is a fair possibility of identification of more potent herbal analogs for curing arthritis, diabetes, and cancer through the application of in silico approach[9]. Although a myriad of literature is available on target-based approach and specific target sites were investigated for the different ligands which did not pave the way for exploring new ligands and their scope for drug repurposing is left behind. Hence, the present investigation worked on a ligand-based method (chemical similarity criteria), which does not guarantee similar bioactivity. For this very purpose bioactivity score at a different target, sites are evaluated, and their binding energy is measured by swiss docking. Although, the objective of docking was not extra precision but to just evaluate the binding energy at a particular class of receptors as estimated by swiss target prediction. The medicinal plants are the least studied facet on this point of view and the scope of innovative drug designing from their active chemical constituents through the application of curative and synthetic pathways is yet to be achieved and untapped. The present discerns that the least investigated and explored aspects of in silico drug designing through innovatively and curatively fabricating drug-like small molecules. Further, the specific molecular docking studies comprising interaction analysis (protein-ligand), replica exchange molecular dynamics (REMD), MM-GBSA, and APBS electro statistics which is validated by Ramachandran torsion plots, this approach may be applied to calculate forces, energies, and binding affinity[9]. These scientific efforts will not only improve the biological efficacy of the current drug but also provide a roadmap for innovative drug development or a fair potential for drug reuse after pathways are revealed at the genomic level[10]. Furthermore, it may be assumed that there is a wide scope for investigation of other members of the Cyperaceae family including Scirpus grossus L., Trichophorum clintonii (Gray) S.G.., and Eleocharis dulcis (Burm.f.) Trin. ex. Hensch. etc. for the development of herbal medicines.

\section{Conclusions}


The current study uses a ligand-based strategy (chemical similarity criteria) to identify the therapeutically developed small drug-like molecule (SA) and compares it to a naturally occurring bioactive ingredient, Cyperene. The bioactivity scores derived using molinspiration cheminformatics provided activity profiles of the ligands at several target locations, and they were subsequently swiss docked based on their highest activity ratings at each site. It sparked some notions regarding their binding energies. The Swiss target prediction created ideas for potential ligand targets, which were then entered into the webGestalt web server software to determine their relationships, signaling cascades, and diseases/ illnesses connected with them. The studies' primary goal is to figure out where ligands might be able to target, how genes connect, how signaling pathways work, and how they relate to the top ten diseases and disorders. This would open the door to more medication development and possible drug repurposing compounds. In a broad sense, the current investigation resulted in the examination of many ligand-target locations as well as their potential mode of action. These findings can then be confirmed by testing the activity of target-specific ligands using molecular mechanics generalized Born surface area continuum solvation (MM-GBSA) to determine their resilience and electrostatic stability. However, this is outside the scope of the current study.

Researchers are pursuing a complete understanding of the herbal therapeutic agent's mechanism of action to demonstrate its potential as a drug for drug reuse and design successor due to its widespread availability in nature and long-term use in a variety of diseases. An in silico technique was used to analyze Cyperus rotundus L., a member of the Cyperaceae family. Cyperene, a major bioactive ingredient of the herbal medication, was examined along with the scaffold analog. The cell signaling, regulating, and regulatory pathways were better understood, thanks to cheminformatics and proteogenomic research. The scaffold analog has better drug similarity and safety characteristics than the originals. The main potential of indigenous medications remains untapped, which may be scientifically researched to meet global demand for pharmaceuticals, according to the findings. Based on this extensive research, it can be deduced that the scaffold analog and the bioactive components, either together or separately, could be promising effective molecules for phytomedicines in additional disorders, as mentioned in the pharmacological analysis.

\section{Declarations}

\section{Conflict of interest}

The authors report no conflicts of interest. The authors are responsible for the content, and writing of this article.

\section{Acknowledgements}

Thanks to Honorable Dr. Chinmay Pandya (Pro-Vice-Chancellor, Dev Sanskriti Vishwavidyalaya) for his kind, unflinching and unwavering motivation. Further, we are obliged to the experts of Medicinal Plants 
(Professor KS), Drug Design Scientists (M K), and renowned Academicians for assisting the work successfully. The present research is self-sponsored and no external funding agency was approached for the purpose.

\section{References}

1. Singh LR, Singh K. Organic Agri-Practices and Pharmacognostic Evaluation of Off- Seasoned Cultivated Madhulika: A Wonder Herb. Int J Pharma Bio Sci 2021;11:19-23. https://doi.org/10.22376/ijpbs/lpr.2021.11.2.p19-23.

2. Singh LR, Singh K. Holistic Therapeutic Approaches for Curing Novel Corona virus: An Overview. Adv PLANT Sci 2020;33:175-9.

3. Raj Singh L. Organic Cultivation and Evaluation of Cyperus Rotundus Linn 2019;6:365-8.

4. Raj Singh, Lalit (Dev Sanskriti Vishwavidyalaya), Karan Singh DS. WILD UNDERUTILIZED MEDICINAL PLANT; MOTHA (Cyperus rotundus L.). Int J Curr Res 2018;10:64617-9.

5. Sumalapao DEP, Villarante NR, Agapito JD, Asaad AS, Gloriani NG. Topological polar surface area, molecular weight, and rotatable bond count account for the variations in the inhibitory potency of antimycotics against microsporum canis. J Pure Appl Microbiol 2020. https://doi.org/10.22207/JPAM.14.1.25.

6. Qazi S, Raza K. Phytochemicals from Ayurvedic plants as potential medicaments for ovarian cancer: an in silico analysis. J Mol Model 2021;27:114. https://doi.org/10.1007/s00894-021-04736-x.

7. Montes-Grajales D, Puerta-Guardo H, Espinosa DA, Harris E, Caicedo-Torres W, Olivero-Verbel J, et al. In silico drug repurposing for the identification of potential candidate molecules against arboviruses infection. Antiviral Res 2020. https://doi.org/10.1016/j.antiviral.2019.104668.

8. Ranjan A, Ramachandran S, Gupta N, Kaushik I, Wright S, Srivastava S, et al. Role of phytochemicals in cancer prevention. Int J Mol Sci 2019;20:1-17. https://doi.org/10.3390/ijms20204981.

9. Isa MA, Mustapha A, Qazi S, Raza K, Allamin IA, Ibrahim MM, et al. In silico molecular docking and molecular dynamic simulation of potential inhibitors of 3C-like main proteinase (3CLpro) from severe acute respiratory syndrome coronavirus-2 (SARS-CoV-2) using selected african medicinal plants. Adv Tradit Med 2020. https://doi.org/10.1007/s13596-020-00523-w.

10. Chetta $M$, Tarsitano M, Vicari L, Saracino A, Bukvic N. In silico analysis of possible interaction between host genomic transcription factors (TFs) and zika virus (ZikaSPH2015) strain with combinatorial gene regulation; virus versus host-the game reloaded. Pathogens 2021. https://doi.org/10.3390/pathogens10010069.

\section{Figures}




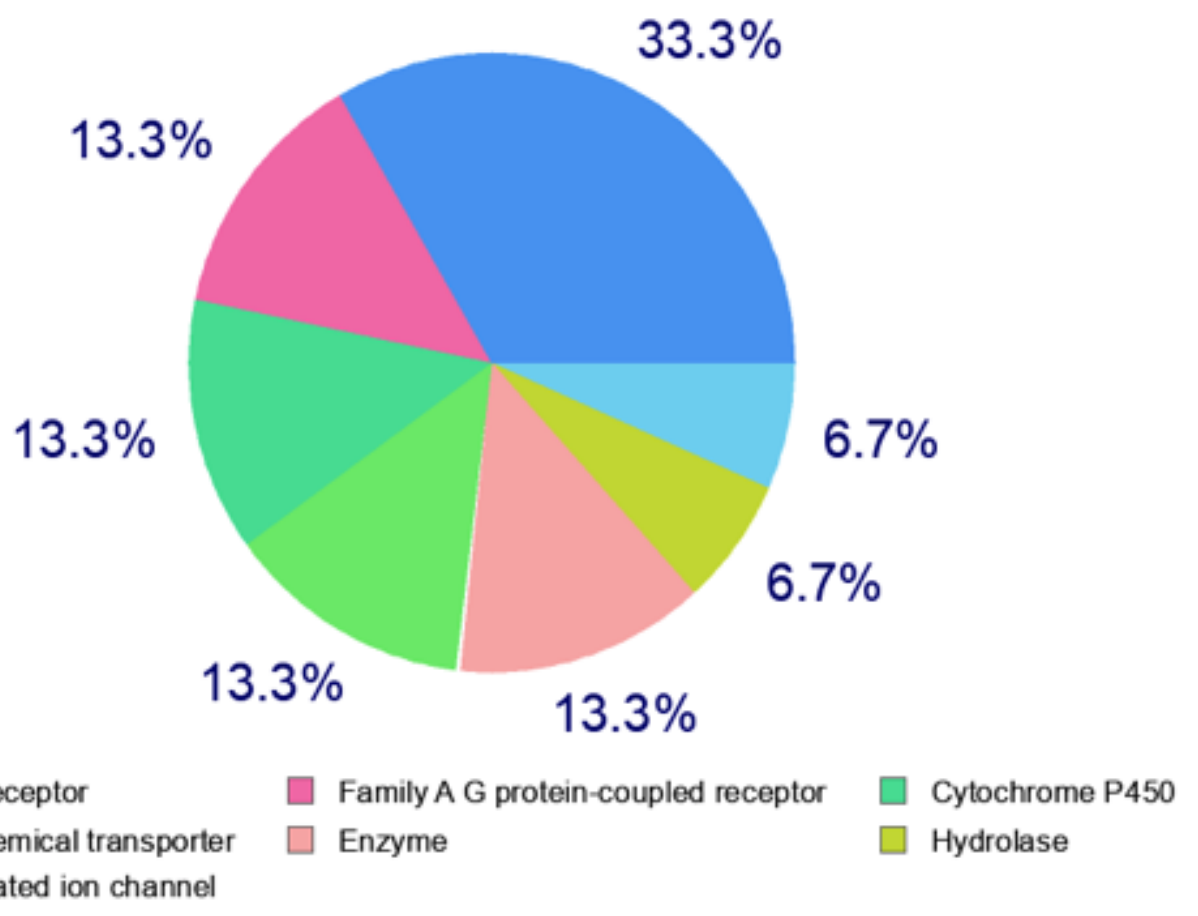

\section{Figure 1}

Showing target sites of Cyperene

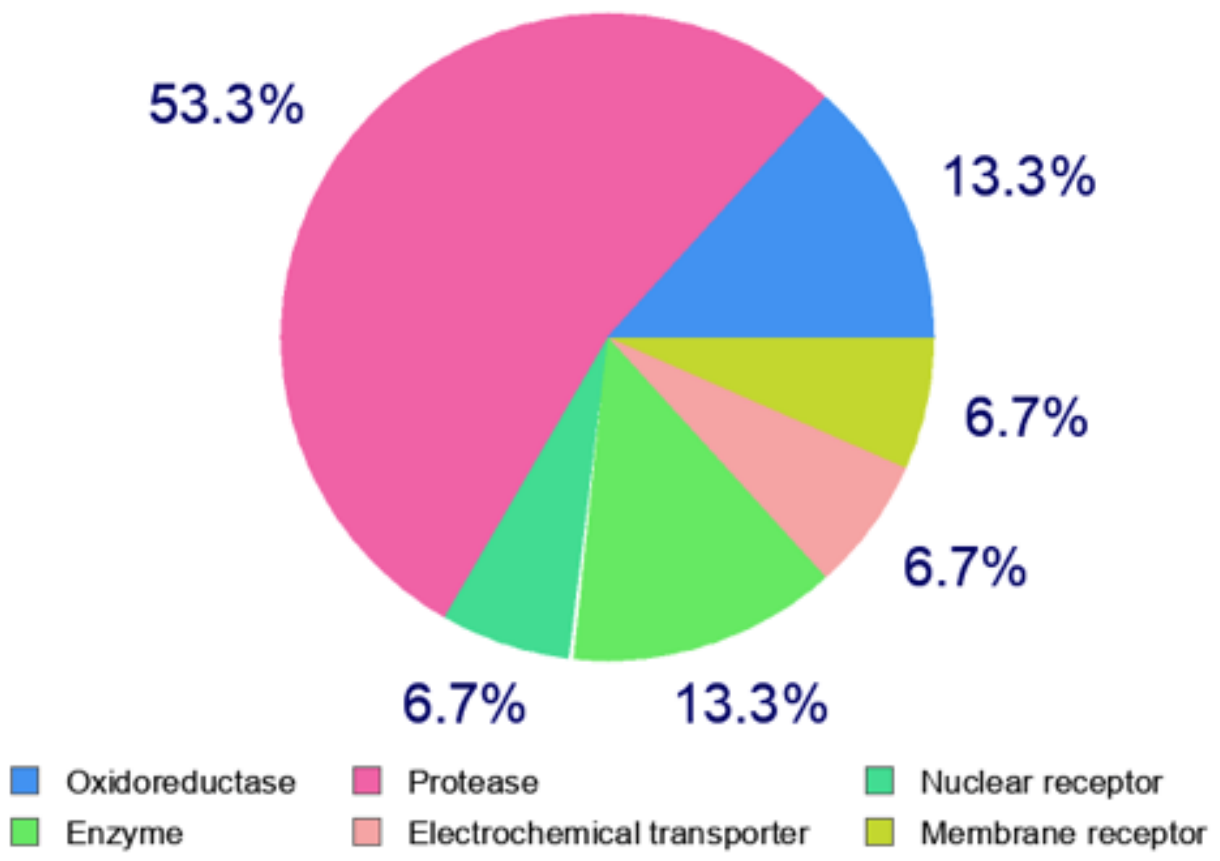

Figure 2

Showing target sites of Scaffold analog (SA) 


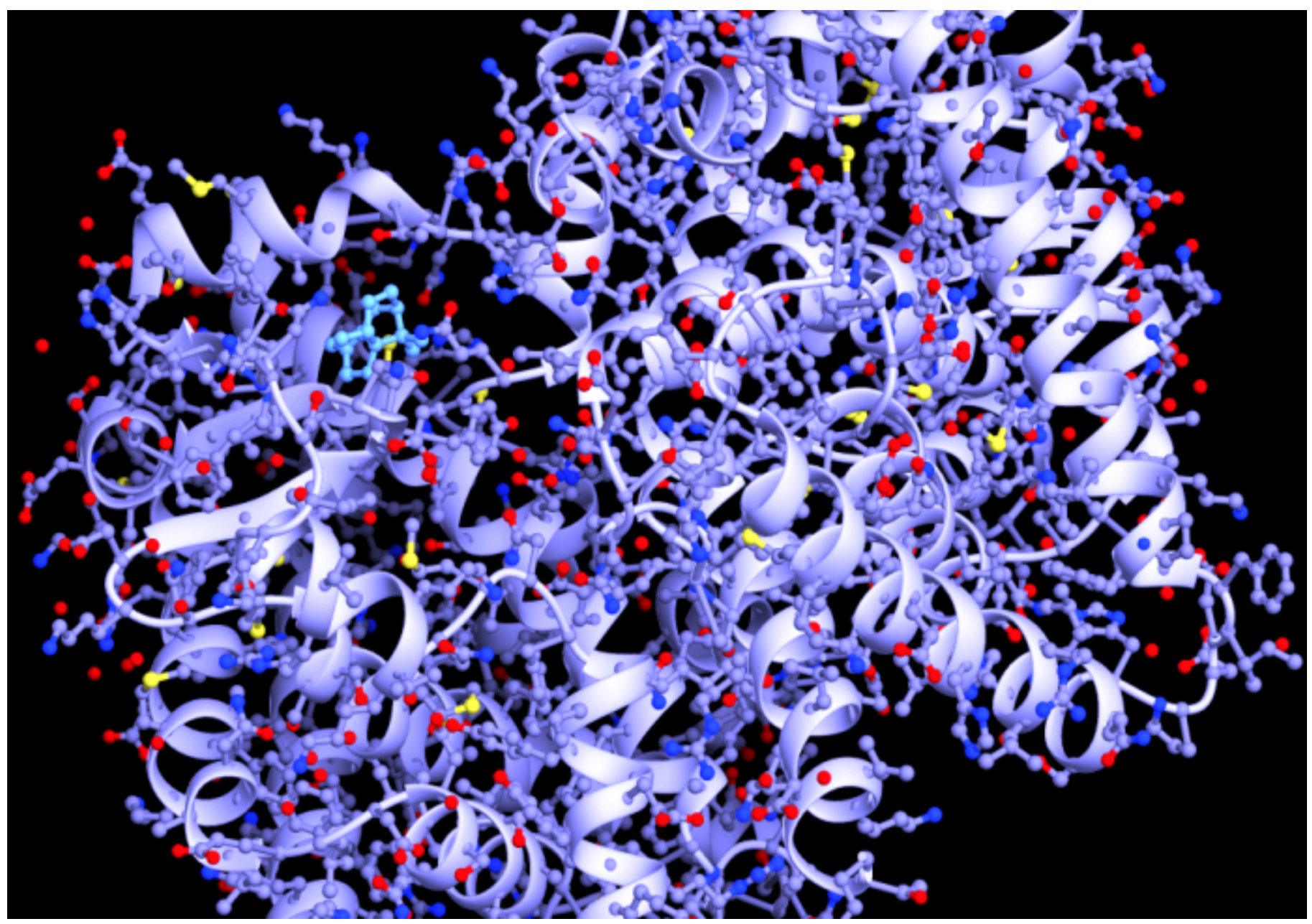

Figure 3

Composite view 


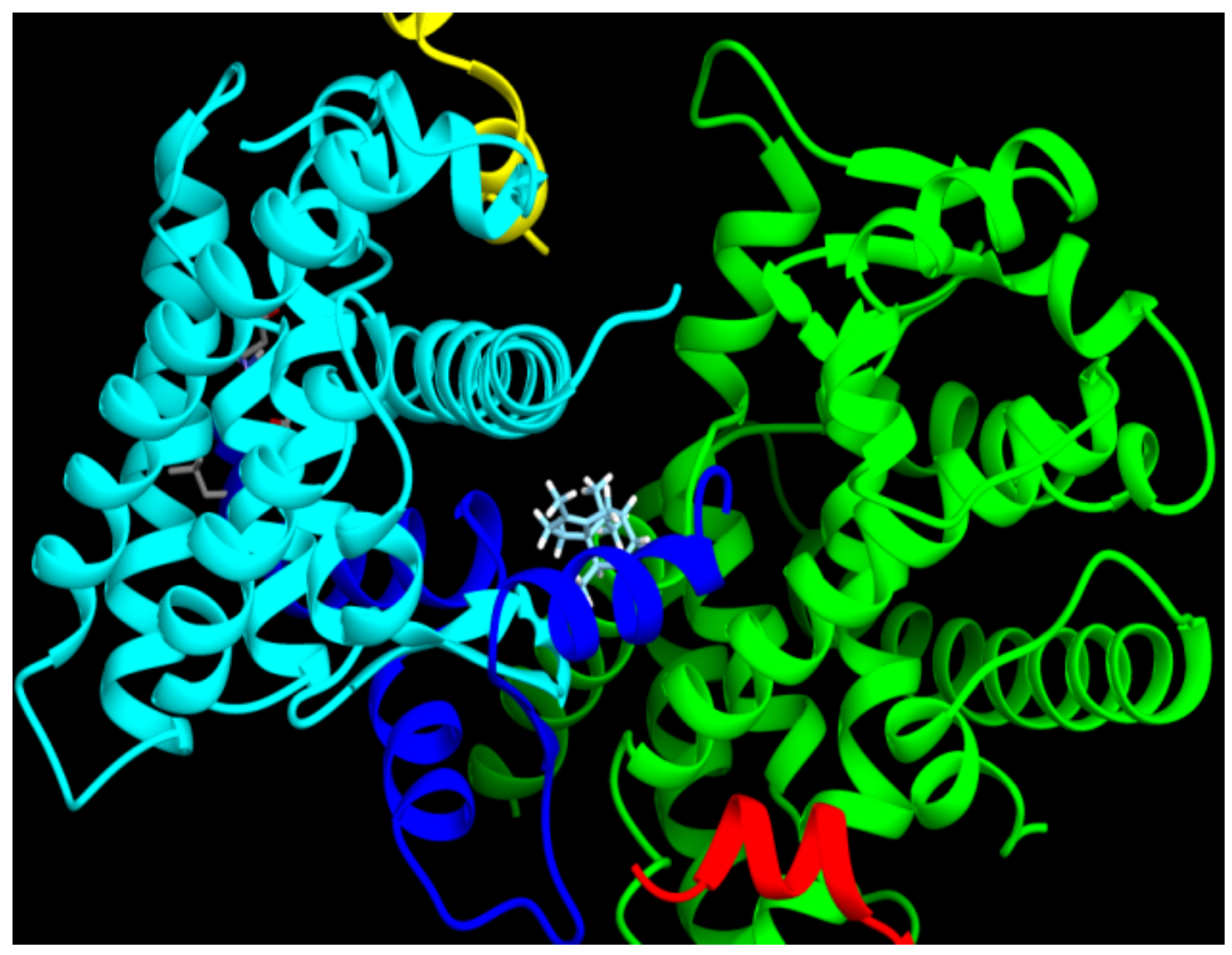

Figure 4

Interactive ribbons 


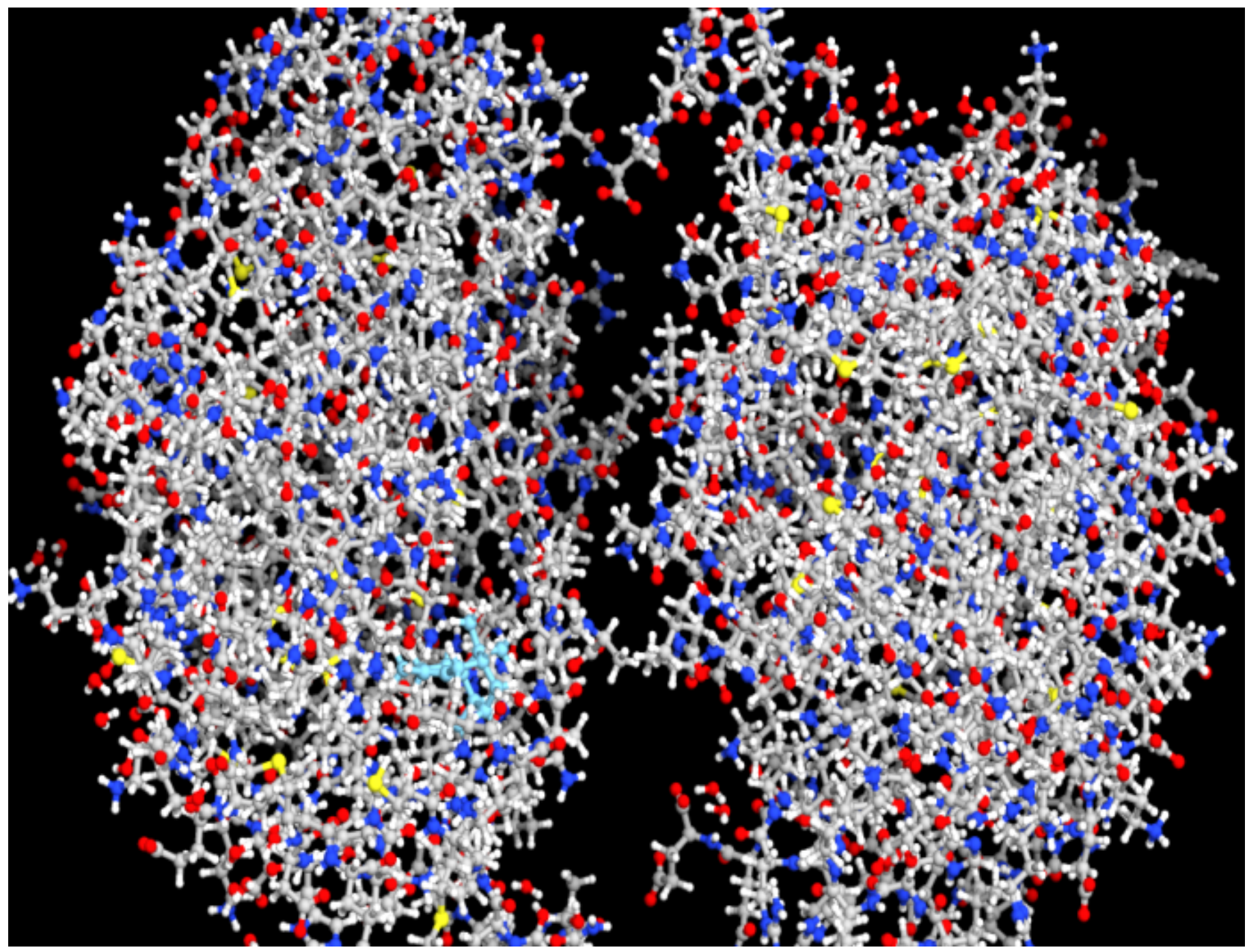

Figure 5

All interactive atoms 


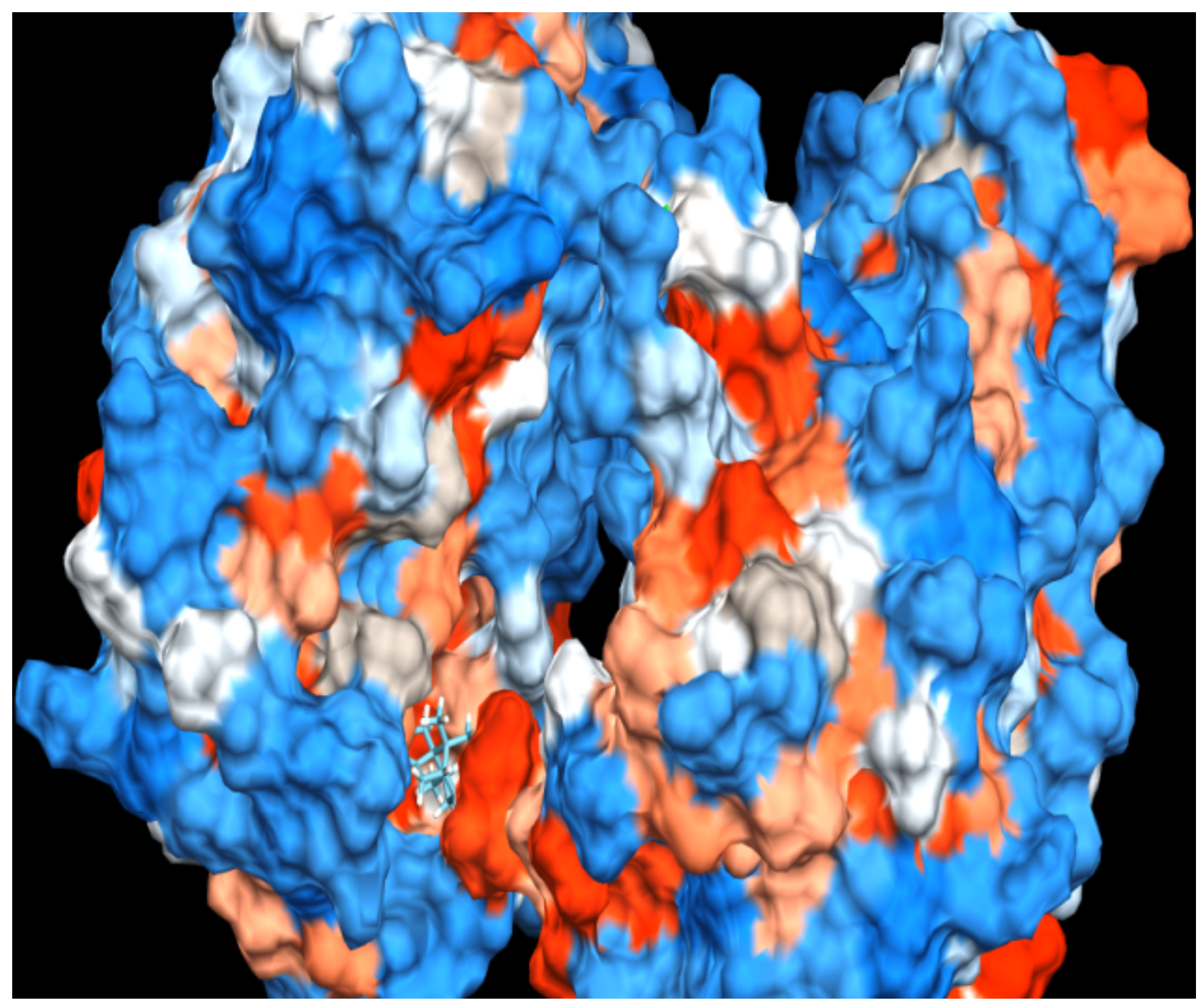

Figure 6

Hydrophobicity surface 


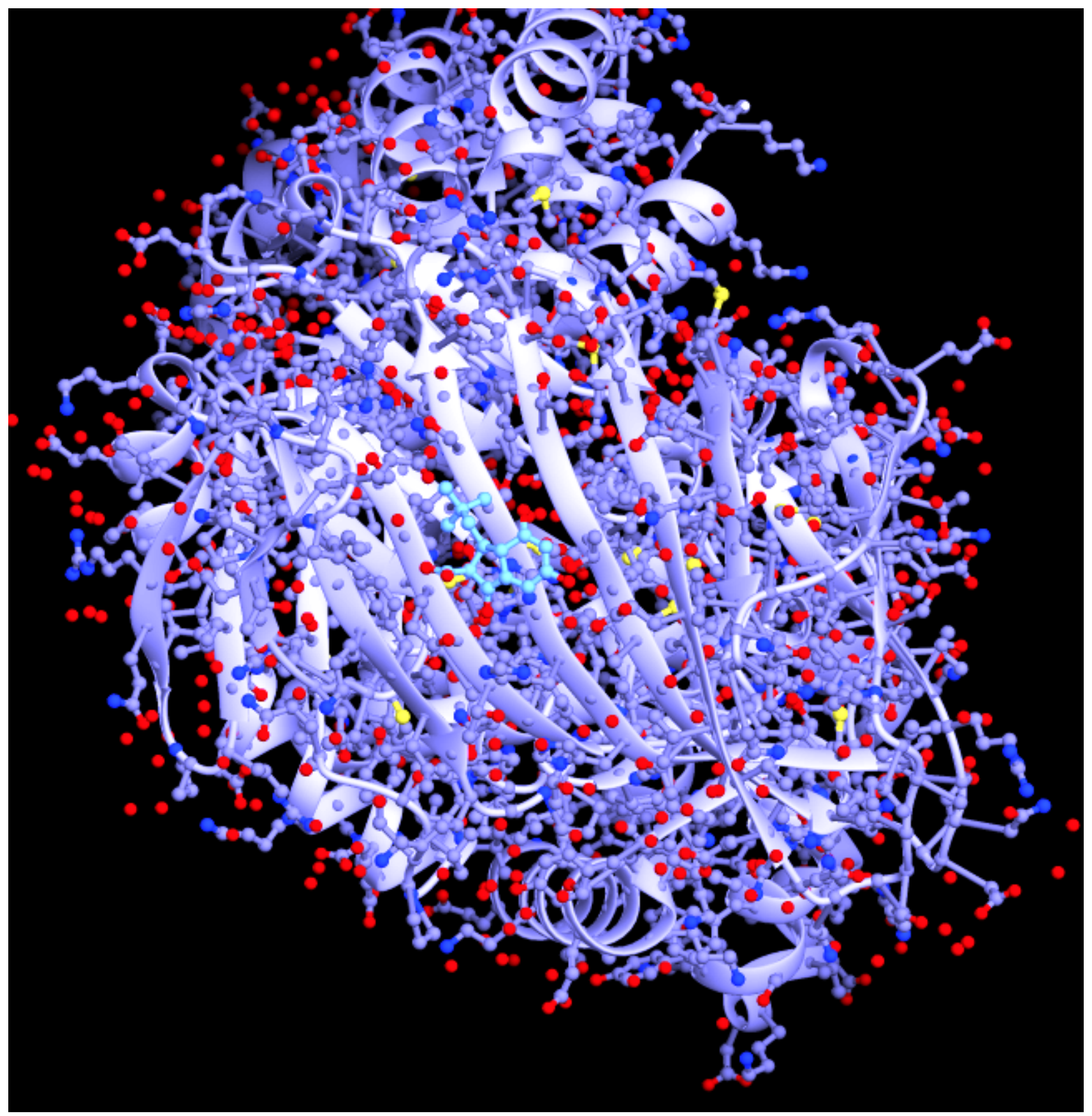

Figure 7

Composite view 


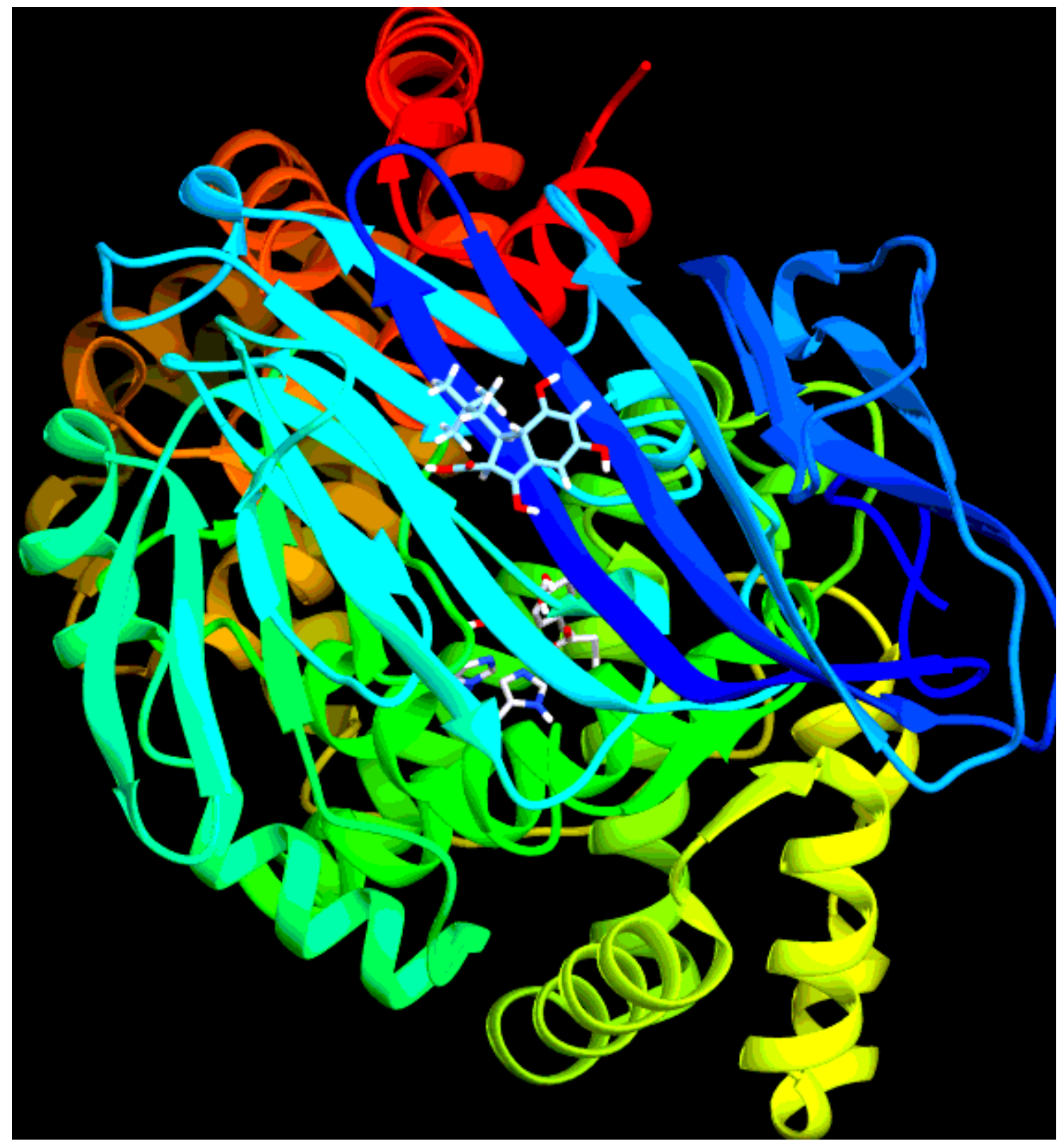

Figure 8

Interactive ribbons 


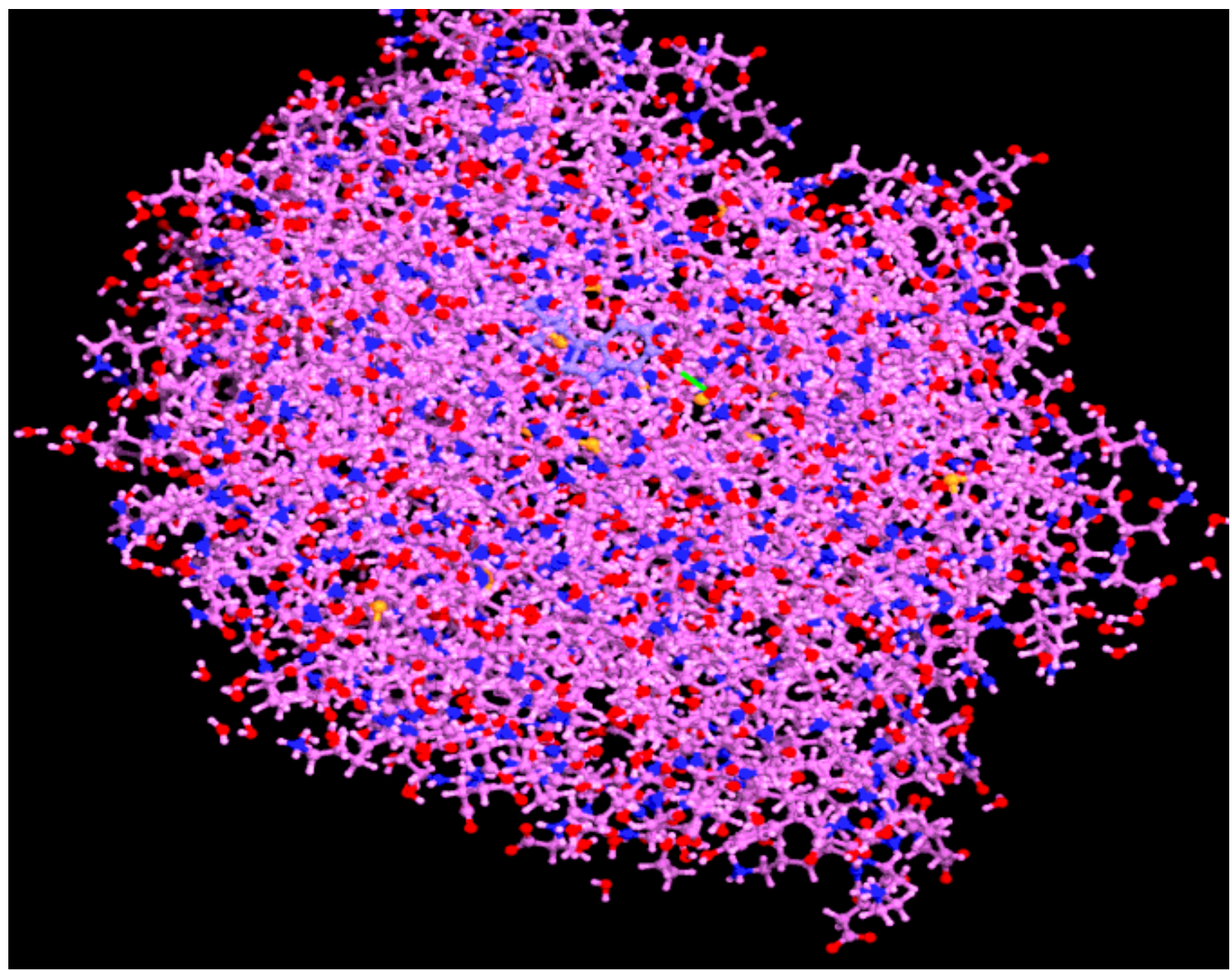

Figure 9

All interactive atoms 


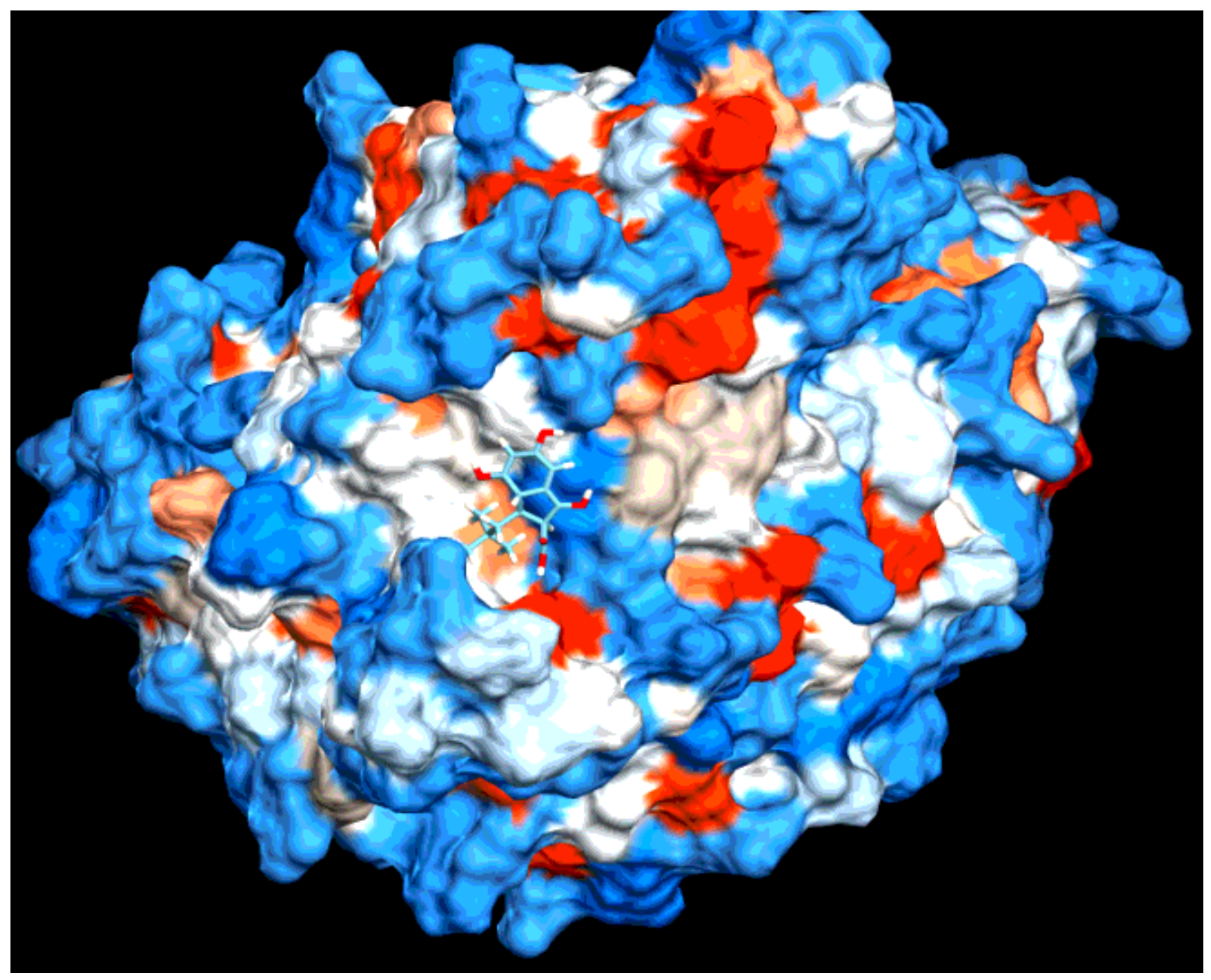

Figure 10

Hydrophobicity surface
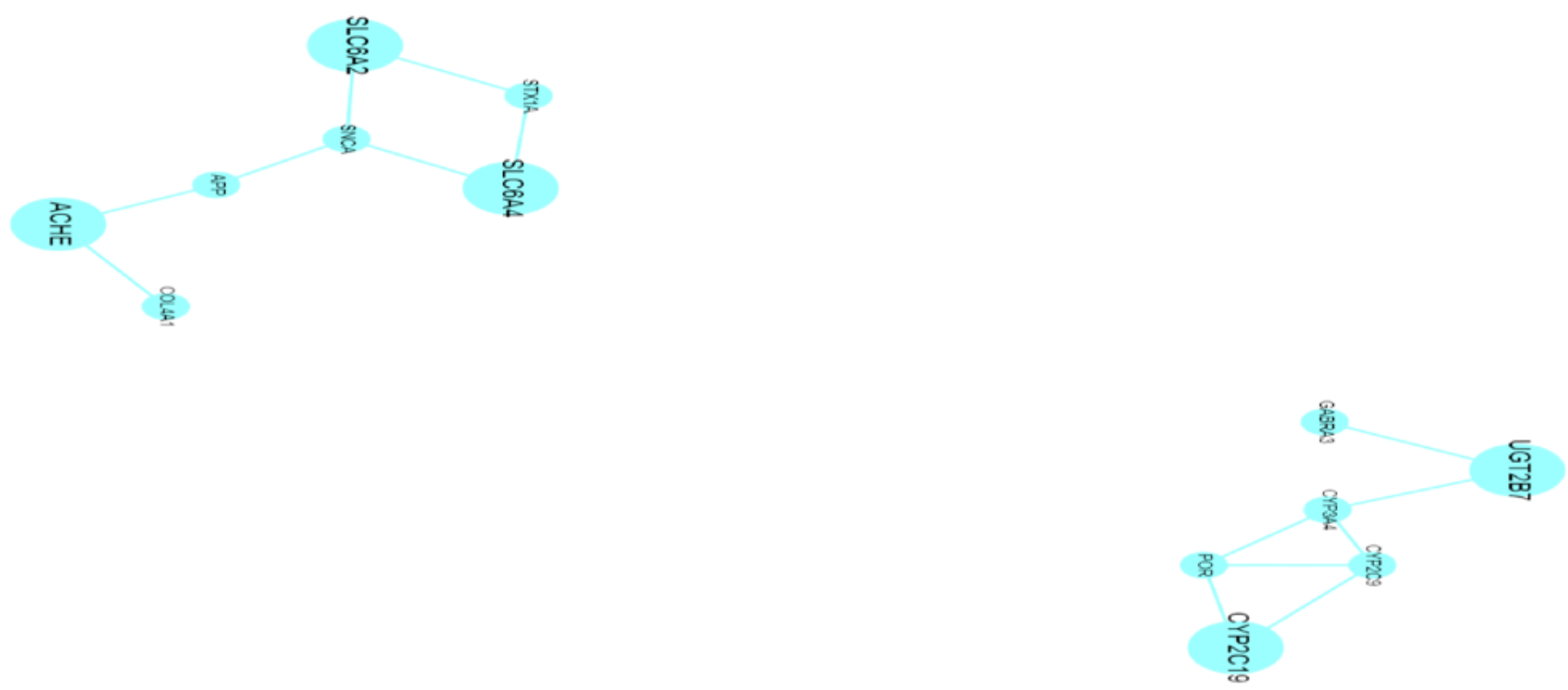


\section{Figure 11}

Figure 9 Showing interaction grid of targeted genes (Cyperene). SLC6A2-Solute carrier family 6 member 2, SLC6A4-Solute carrier family 6 member 4, UGT2B7-UDP Glucuronosyltransferase family 2 member B7, ACHE-Acetylcholinesterase, COL4A1-Collagen type IV alpha 1, APP-Amyloid beta precursor protein, SNCAAlpha-synuclein, STX1A-Syntaxin 1A, CYP2C19-Cytochrome P450 family 2 subfamily C member 19, PORCytochrome P450 Oxidoreductase, CYP2C9-Cytochrome P450 family 2 subfamily C member 9, CYP3A4Cytochrome P450 family 3 subfamily A member 4, GABRA3-Gamma-aminobutyric acid type A receptor subunit alpha 3.

FDR $\leq 0.05 \quad \mathrm{FDR}>0.05$

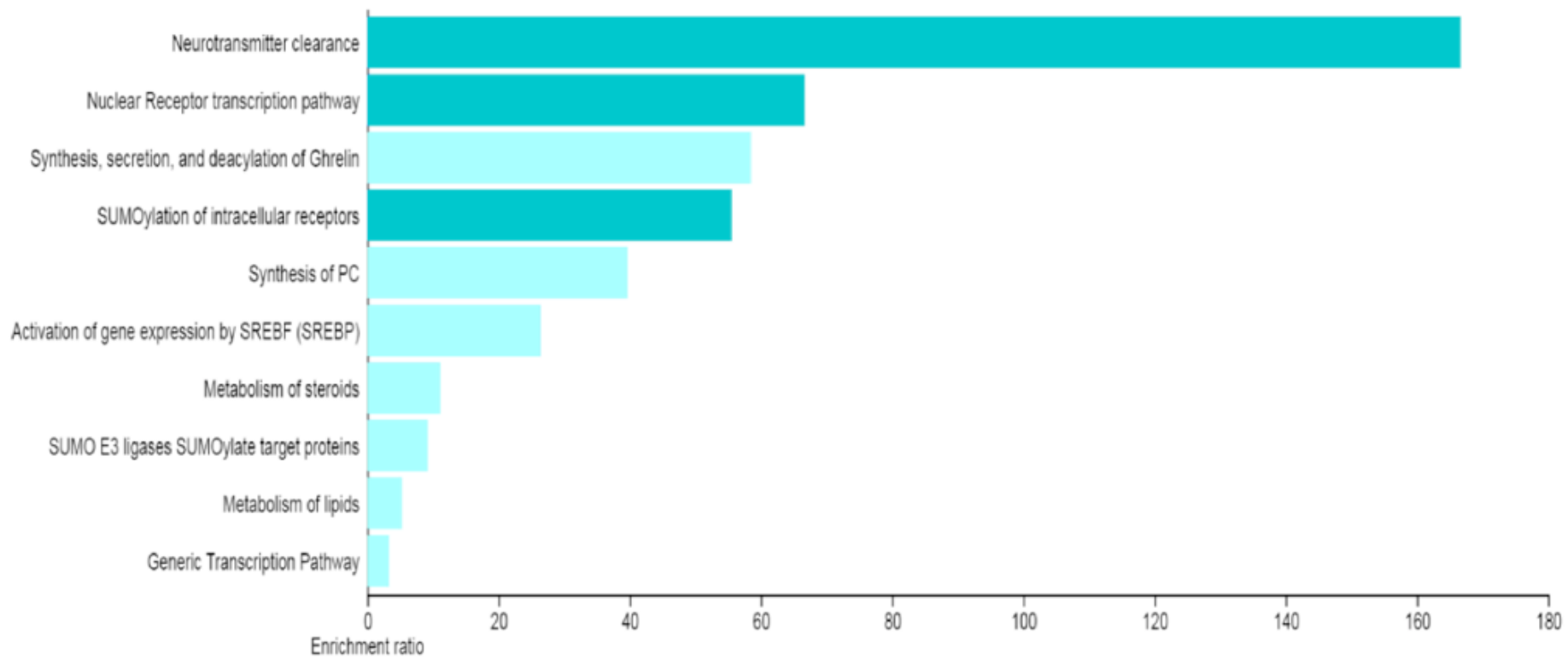

\section{Figure 12}

Figure 10 Showing cellular signaling pathways of targeted genes (Cyperene)

$=\mathrm{FDR} \leq 0.05 \quad \mathrm{FDR}>0.05$

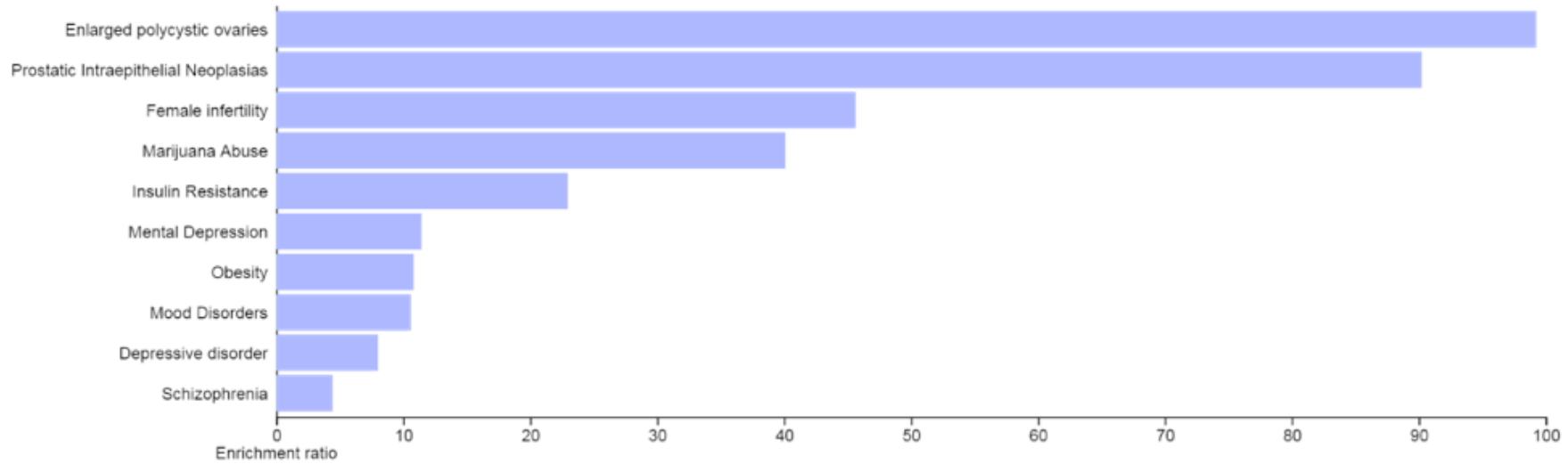

\section{Figure 13}

Figure 11 Showing top ten diseases/disorders controlled by the grid of targeted genes of Cyperene 

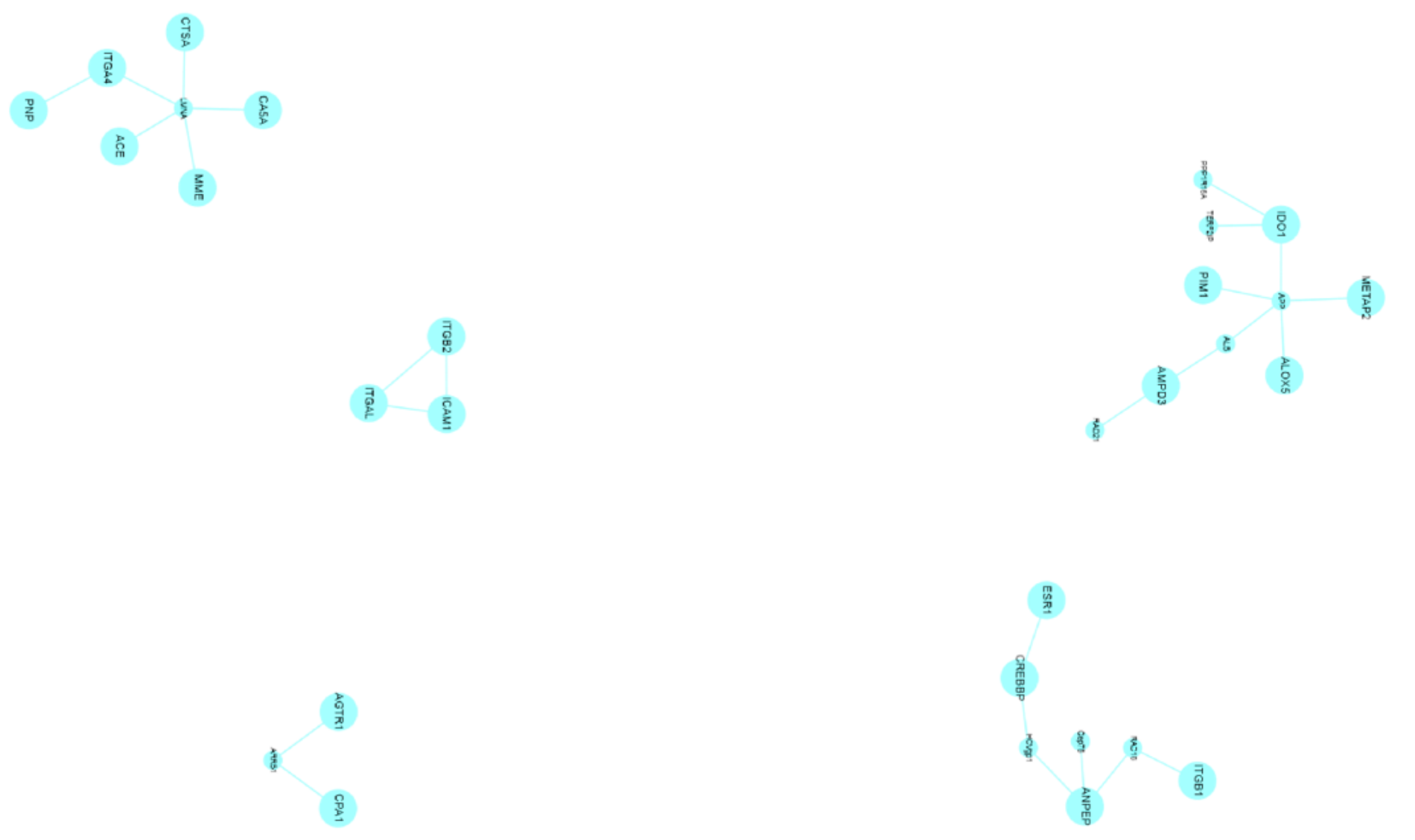

\section{Figure 14}

Figure 12 Showing interaction grid of targeted genes (Scaffold Analog). ALOX5-Arachidonate 5Lipoxygenase, ACE-Angiotensin converting enzyme, ESR1-Estrogen receptor 1, ID01-Indoleamine 2,3dioxygenase 1, METAP2-Methionyl aminopeptidase 2, CPA1-Carboxypeptidase A 1, MME-Membrane metallo endopeptidase, ITGAL-Integrin subunit alpha-L, ICAM1-Intercellular adhesion molecule 1, ITGB2Integrin subunit beta 2, ANPEP-Alanyl aminopeptidase membrane, AMPD3-Adenosine monophosphate deaminase 3, PIM1-Pim-1 Proto-Oncogene, CREBBP-CREB binding protein, CTSA-Cathepsin A, ITGB1Integrin subunit beta 1, ITGA4-Integrin alpha-4 precursor, AGTR1-Angiotensin II receptor type 1, CA5ACarbonic anhydrase 5A, ALB-Albumin, PPP1R16A-Protein phosphatase 1 regulatory subunit 16A, TERF2IP-Telomeric repeat-binding factor 2-interacting protein 1, CEP76-Centrosomal protein 76, PNPPurine nucleoside phosphorylase, LMNA-Lamin A/C, ARRB1-Arrestin beta 1, HCVgp1-Hepacivirus C, RAD18-RAD 18 E3 Ubiquitin protein ligase, RAD21-RAD 21 cohesin complex component, APP-Amyloid beta precursor protein. 


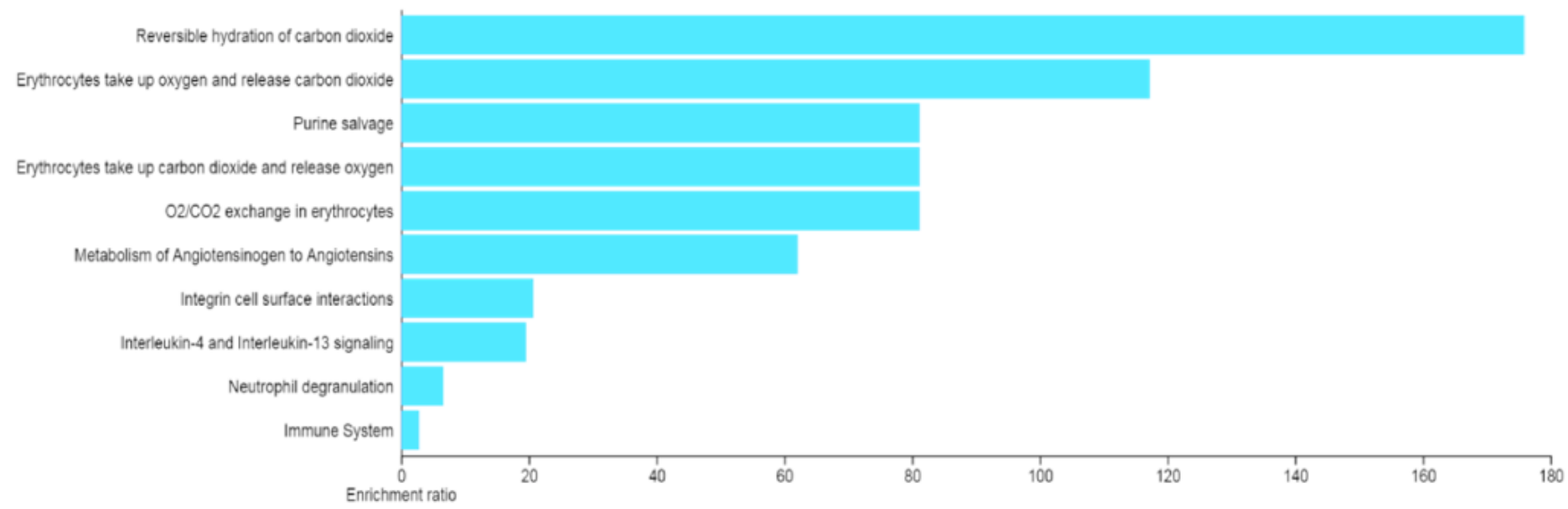

\section{Figure 15}

Figure 13 Showing cellular signaling pathways of targeted genes

FDR $\leq 0.05 \quad \mathrm{FDR}>0.05$

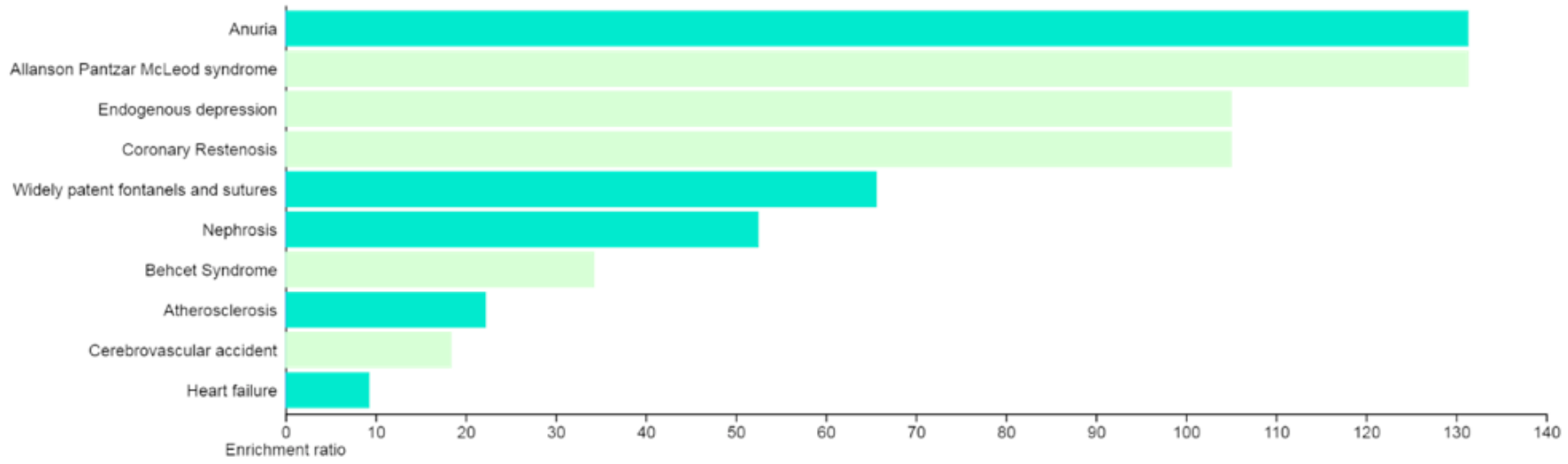

\section{Figure 16}

Figure 14 Showing top ten diseases/disorders controlled by the grid of targeted genes of Scaffold Analog

\section{Supplementary Files}

This is a list of supplementary files associated with this preprint. Click to download.

- floatimage1.png 